\title{
Inductive Effects in Neighboring-Group Participation. Destabilization of Carbocations by CC Double Bonds in Solvolyses of 2,2,5,5-Tetramethylcyclopent-3-en-1-yl Tosylates
}

\author{
T. William Bentley, ${ }^{*, \dagger}$ Bernhard Irrgang, ${ }^{\ddagger}$ Herbert Mayr, ${ }^{\ddagger}$ and Paul von Raguê Schleyer ${ }^{\S}$ \\ Department of Chemistry, University College of Swansea, Singleton Park, Swansea SA2 8PP, U.K., Institut für \\ Chemie, Medizinische Universität zu Lübeck, D-2400 Lübeck, West Germany, and Institut für Organische \\ Chemie der Friedrich-Alexander Universität Erlangen-Nürnberg, D-8520 Erlangen, West Germany
}

Received November 17, 1987

\begin{abstract}
The possibility of homoallylic participation in solvolyses of substituted cyclopent-3-en-1-yl sulfonates has been investigated. Relative rates of solvolyses of 2,2,5,5-tetramethylcyclopentyl (6), 2,2,3,4,5,5-hexamethylcyclopent-3-en-1-yl (13), 2,2,5,5-tetramethyl-3,4-bis(methylene)cyclopent-1-yl (16), and 2,2,5,5-tetramethylcyclopent-3-en-1-yl (18) tosylates in $80 \%(\mathrm{v} / \mathrm{v})$ ethanol/water at $95{ }^{\circ} \mathrm{C}$ are 128:5.9:5.4:1. Measures of solvent effects on the reactivity of tetramethylcyclopentyl tosylate $6\left(m=0.88, Q^{\prime}=0.94\right)$ confirm the expectation that nucleophilic solvent participation (if any) is very weak, and the large destabilizing effect of the double bond in the cyclopent-3-en-1-yl cation, predicted by theoretical calculation, is now confirmed experimentally. Diene products arising from 1,2-methyl shifts dominate. Solvolytic data in weakly nucleophilic media (e.g., hexafluoroisopropyl alcohol) show that $\beta$-methyl and $\beta, \beta$-dimethyl substitution increase the solvolysis rate of cyclopentyl tosylate cumulatively, but the tetramethyl derivative shows anomalously low reactivity, possibly due to steric inhibition of solvation and of departure of the leaving group.
\end{abstract}

Opposing substituent effects (e.g., electron withdrawal by induction and electron donation by conjugation) are well established in organic chemistry. ${ }^{1}$ These effects can be quantified by empirical parameters ${ }^{2}$ or by theoretical analyses of $\sigma$ and $\pi$ contributions. ${ }^{3}$ Typically such behavior is observed when substituents are located directly at, or are conjugated with, the reaction center. More remote substituents may also exhibit opposing $\sigma$ and $\pi$ effects. Many reactions involve neighboring-group participation by electron-pair donation from atoms that simultaneously withdraw electrons (e.g., $\mathrm{RO}, \mathrm{Br}, \mathrm{C}=\mathrm{C}$ ). ${ }^{4 \mathrm{a}}$ In such cases, the magnitude of the kinetic effects associated with anchimeric assistance is difficult to separate from the rate retardations caused by the simultaneous electron withdrawal. ${ }^{4 b}$ For simplicity we will refer to these latter influences as inductive effects. ${ }^{4 b}$

For neighboring-group participation by alkenyl or $\beta$-aryl groups, inductive effects have been noted, but have usually been regarded as small (up to about a power of ten in rate). ${ }^{4 b, 5,6}$ These effects complicate the interpretation of solvolyses of 2-exo-norbornenyl tosylate $(1, \mathrm{X}=\mathrm{OTs})$, which reacts $1 / 3$ as fast as 2-exo-norbornyl tosylate $(2, \mathrm{X}$ $=\mathrm{OTs}) .{ }^{5 \mathrm{a}}$ When large rate accelerations are encountered, e.g., with 7-anti-norbornenyl tosylate $(3, \mathrm{X}=\mathrm{OTs})$, which reacts $10^{11}$ times faster than the parent 7-norbornyl $4,^{7}$ corrections for inductive effects have been neglected. However, there are indications that large inductive effects are also possible (Scheme I). Comparison between acetolyses of the tetramethylindanyl tosylate 5 and the parent tetramethylcyclopentyl tosylate $6(\mathrm{X}=\mathrm{OTs})$, an example directly pertinent to the present work, indicated a rate retardation of 48 caused by the benzene ring. ${ }^{8}$ Also 2endo-norbornenyl tosylate ( $7, \mathrm{X}=\mathrm{OTs}$ ) solvolyzes 44 times slower than 2-endo-norbornyl tosylate $(8, \mathrm{X}=\mathrm{OTs}),{ }^{7 \mathrm{~b}, 9}$ the corresponding tertiary 2 -methyl- $p$-nitrobenzoates show a rate ratio of $21.5,{ }^{10 a}$ and exo-bicyclo[4.1.0]hept-2-en-7-yl triflate solvolyzes 50 times more slowly than the dihydro analogue. ${ }^{10 \mathrm{~b}}$ An inductive effect of even larger magnitude is indicated for the cyclopent-3-en-1-yl cation by high level ab initio molecular orbital calculations. ${ }^{9}$ In this paper we provide experimental verification for the larger inductive

\footnotetext{
${ }^{\dagger}$ Swansea.

${ }^{\ddagger}$ Lübeck.

\& Erlangen
}

Scheme I

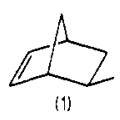

$k_{\text {rat }} 0.3: 1$

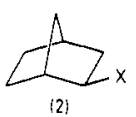

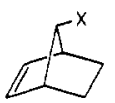

(3)

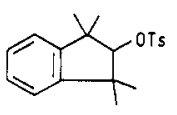

(5)

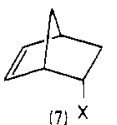

(7) $x$

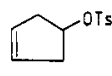

(9)

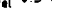

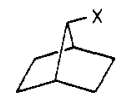

(4)

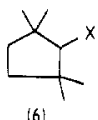

(6)
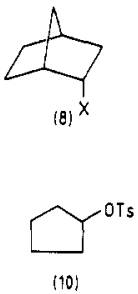

destabilization of carbocations by a $\mathrm{CC}$ double bond, and we discuss the general implications of these results.

(1) Ingold, C. K. Structure and Mechanism in Organic Chemistry, 2nd ed.; Cornell University: New York, 1969; pp 78-114.

(2) Swain, C. G.; Unger, S. H.; Rosenquist, N. R.; Swain, M. S. J. Am. Chem. Soc. 1983, 105, 492.

(3) Hehre, W. J.; Radom, L.; Schleyer, P. v. R.; Pople, J. A. Ab Initio Molecular Orbital Theory; Wiley: New York, 1986; pp 346-369.

(4) (a) Capon, B.; McManus, S. P. Neighboring Group Participation; Plenum: New York, 1976. (b) Lancelot, C. J.; Cram, D. J.; Schleyer, P. v. R. In Carbonium Ions; Olah, G. A., Schleyer, P. v. R., Eds.; Wiley: New York, 1972; Vol. 3, Chapter 27, pp 1369-1375.

(5) (a) Lambert, J. B.; Holcomb, A. G. J. Am. Chem. Soc. 1971, 93, 2994. (b) Lambert, J. B.; Featherman, S. I. J. Am. Chem. Soc. 1977, 99, 1542. (c) Peterson, P. E.; Chevli, D. M. J. Org. Chem. 1974, 39, 3684. (d) Ando, T.; Yamawaki, J.; Saito, Y. Bull. Chem. Soc. Jpn. 1978, 51, 219. (e) Ferber, P. H.; Gream, G. E. Aust. J. Chem. 1981, 34, 1051.

(6) Harris, J. M.; Moffat, J. R.; Case, M. G.; Clarke, F. W.; Polley, J. S.; Morgan, T. K., Jr.; Ford, T. M.; Murray, R. K., Jr. J. Org. Chem. 1982 47,2740 .

(7) (a) Winstein, S.; Shatavsky, M.; Norton, C.; Woodward, R. B. J. Am. Chem. Soc. 1955, 77, 4183. (b) Winstein, S.; Shatavsky, M. J. Am. Chem. Soc. 1956, 78, 592. (c) Winstein, S.; Stafford, E. T. J. Am. Chem. Soc. $1957,79,505$. 
Scheme II
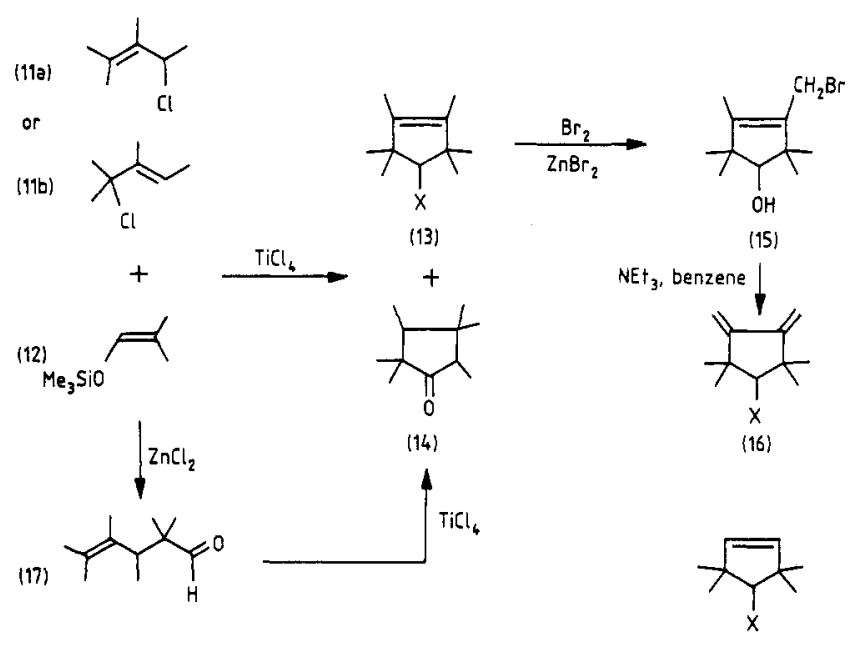

(18)

Our recent interest in this topic began with the report that cyclopent-3-en-1-yl tosylate (9) solvolyzed in formic acid by homoallylic participation without a rate enhancement. ${ }^{11}$ Even in the weakly nucleophilic solvent hexafluoroisopropyl alcohol (HFIP), the unsaturated system 9 reacted 8 times more slowly than the saturated cyclopentyl system $10 .^{9}$ These results have been rationalized, ${ }^{9}$ but their interpretation was complicated by the possible occurrence of nucleophilic solvent assistance $\left(k_{\mathrm{s}}\right.$ character) in solvolyses of both the saturated and the unsaturated tosylates. To reduce substantially the complications caused by $k_{\mathrm{g}}$ character, we have now studied solvolyses of the following sterically hindered tosylates: 2,2,5,5-tetramethylcyclopentyl $(6, \mathrm{X}=\mathrm{OTs}),{ }^{8} 2,2,3,4,5,5-$ hexamethylcyclopent-3-en-1-yl (13, X = OTs), 2,2,5,5tetramethyl-3,4-bis(methylene)cyclopent-1-yl (16, X = OTs), and 2,2,5,5-tetramethylcyclopent-3-en-1-yl (18, X = OTs).

\section{Results}

Syntheses. For the alcohols 13 and $16(\mathrm{X}=\mathrm{OH})$, a formal $\left[3^{+}+2\right]$ cycloaddition route ${ }^{12}$ has been employed (Scheme II). Treatment of a mixture of the allylic isomers $11 \mathbf{a}, \mathbf{b}$ and of the silyl enol ether 12 with $\mathrm{TiCl}_{4}$ at $-78^{\circ} \mathrm{C}$ yielded the cyclic compounds $13(\mathrm{X}=\mathrm{OH}, 65 \%)$ and 14 $(25 \%)$. It can be assumed that these products are formed via cyclization of the intermediate $17,{ }^{13}$ since this aldehyde, the sole product of the $\mathrm{ZnCl}_{2}$-catalyzed reaction of $11 \mathrm{a}, \mathbf{b}$ with 12 , is converted into a mixture of $13(\mathrm{X}=\mathrm{OH})$ and 14 in the presence of $\mathrm{TiCl}_{4}$. The formation of the undesired side product 14 can be rationalized by protonation of the double bond of $13(\mathrm{X}=\mathrm{OH})$, to give a carbocation followed by sequential methyl and hydride 1,2-shifts; the mechanism is analogous to that suggested for the formation of 14 by acid treatment of 4-methoxy-1,2,3,3,5,5-hexamethylcyclopentene. ${ }^{12 b}$ Compound $13(\mathrm{X}=\mathrm{OH})$ shows

(8) (a) Horn, D. E.; Krapcho, A. P.; Grenon, B. J. J. Org. Chem. 1979, 44, 454. (b) Krapcho, A. P.; Horn, D. E. Tetrahedron Lett. 1966, 6107.

(9) Schleyer, P. v. R.; Bentley, T. W.; Koch, W.; Kos, A. J.; Schwarz H. J. Am. Chem. Soc. 1987, 109,6953.

(10) (a) Brown, H. C.; Peters, E. N. J. Am. Chem. Soc. 1975, 97, 7442 (b) Creary, X. J. Am. Chem. Soc. 1976, 98, 6608.

(11) Lambert, J. B.; Finzel, R. B. J. Am. Chem. Soc. 1983, 105, 1954

(12) (a) Klein, H.; Mayr, H. Angew. Chem. 1981, 93, 1069; Angew. Chem., Int. Ed. Engl. 1981, 20, 1027. (b) Klein, H. Dissertation, Universität Erlangen-Nürnberg, 1982. (c) Baran, J.; Klein, H.; Schade, C.; Will, E.; Koschinsky, R.; Bäuml, E.; Mayr, H. Tetrahedron 1988, 44, 2181.

(13) Similar cyclizations have been reported previously: Andersen, $\mathrm{N}$ H.; Hadley, S. W.; Kelly, J. D.; Bacon, E. R. J. Org. Chem. 1985, 50, 4144

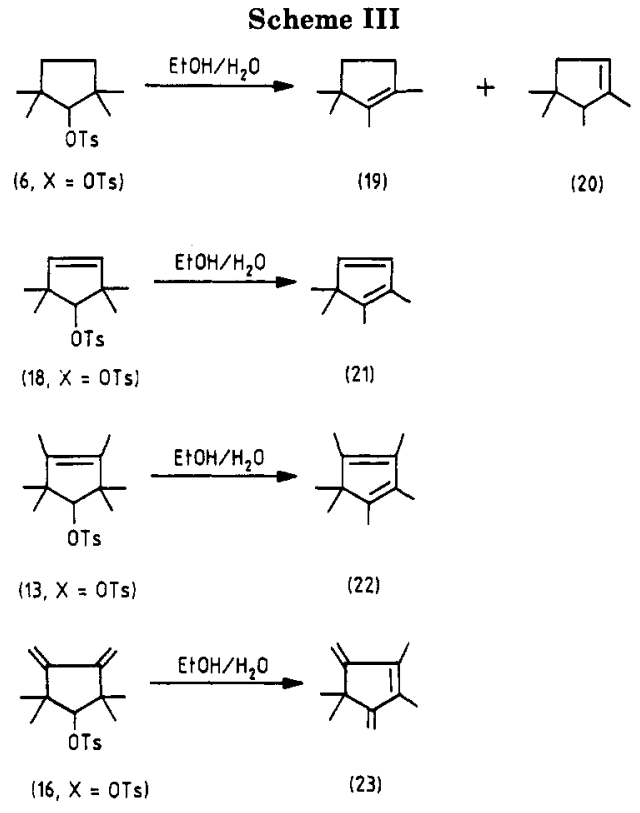

similar reactivity toward bromine as octamethylcyclopentene, ${ }^{14}$ and treatment of $13(\mathrm{X}=\mathrm{OH})$ with bromine in the presence of zinc bromide gave the allylic bromide 15 , which was converted into $16(\mathrm{X}=\mathrm{OH})$ by treatment with triethylamine. The four alcohols $6,13,16$, and 18 (X $=\mathrm{OH}$ ) were converted to the corresponding tosylates by standard procedures.

Products. When solvolyses were carried out in $\simeq 0.05$ M unbuffered $80 \%$ ethanol/water solutions, black tarry mixtures were obtained. Addition of a slight excess of 2,6-lutidine prevented this decomposition, and ${ }^{1} \mathrm{H}$ NMR spectra of the products could be obtained. The cyclopentene derivative 19, which was reported to be the only acetolysis product of $6(\mathrm{X}=\mathrm{OTs}),{ }^{8}$ is also the major component obtained in $80 \%$ ethanol/water (s at $\delta 0.95$ and 2 br $\mathrm{s}$ at $\delta 1.45$ and 1.57) (Scheme III). According to GC, 19 is accompanied by $20 \%$ of an isomer, tentatively assigned structure 20 on the basis of a ${ }^{1} \mathrm{H}$ NMR absorption at $\delta 5.18(\mathrm{~m})$. Solvolysis of $18(\mathrm{X}=\mathrm{OTs})$ in $80 \%$ etha$\mathrm{nol} /$ water gave only one product, the cyclopentadiene 21 with ${ }^{1} \mathrm{H}$ NMR absorptions at $\delta 1.0(\mathrm{~s}, 6 \mathrm{H}), 1.67(\mathrm{br} \mathrm{s}, 3$ $\mathrm{H}), 1.78(\mathrm{br} \mathrm{s}, 3 \mathrm{H})$, and $6.03,6.12$ (AB system with $J=$ $7 \mathrm{~Hz}$ ) and a UV maximum at $\lambda=256 \mathrm{~nm}$. Similarly, compound $13(\mathrm{X}=\mathrm{OTs})$ gave hexamethylcyclopentadiene (22) exclusively, as deduced from the two-line ${ }^{1} \mathrm{H}$ NMR spectrum ( $\mathrm{s}$ at $\delta 0.87$ and br s at $\delta 1.73$, ratio $1: 2$ ) and the UV maximum at $256 \mathrm{~nm} .{ }^{15}$ A $2 \%$ solution of $16(\mathrm{X}=$ OTs) gave a complex mixture with intense ${ }^{1} \mathrm{H}$ NMR absorptions at $\delta 0.93,1.87,4.67$, and 4.80 , in accord with structure 23.

These conclusions were corroborated by investigating the solvolysis products in ca. $10^{-3} \mathrm{M}$ unbuffered solutions by reversed-phase high-performance liquid chromatography. With diode-array detection, UV spectra of separated components of the reaction mixture were obtained. The product composition from $16(\mathrm{X}=\mathrm{OTs})$ after $2 \mathrm{~h}$ at 95 ${ }^{\circ} \mathrm{C}$ was very similar to that after 2 days. The predominant product had $\lambda_{\max }=270 \mathrm{~nm}$, consistent with the value of $274 \mathrm{~nm}$ expected on the basis of Woodward's rules ${ }^{16 a}$ for the triene 23 identified by ${ }^{1} \mathrm{H}$ NMR (see above). Although

(14) Mayr, H.; Will, E.; Heigl, U. W.; Schade, C. Tetrahedron 1986, 42,2519 .

(15) De Vries, L. J. Org. Chem. 1960, 25, 1838.

(16) (a) Williams, D. H.; Fleming, I. Spectroscopic Methods in Organic Chemistry; McGraw-Hill: London, 1980; p 12. (b) Booker, H.; Evans, L. K.; Gillam, A. E. J. Chem. Soc. 1940, 1453. 
Table I. Solvolytic Rate Constants for Solvolyses of Tosylates in $80 \%(\mathrm{v} / \mathrm{v})$ Ethanol/Water ${ }^{a}$

\begin{tabular}{|c|c|c|c|c|}
\hline tosylate & $\stackrel{\text { temp, }}{{ }^{\circ} \mathrm{C}}$ & $k, \mathrm{~s}^{-1}$ & $\begin{array}{c}\Delta H^{*}, \\
\mathrm{kcal} / \\
\mathrm{mol}\end{array}$ & $\begin{array}{c}\Delta S^{*} \\
\mathrm{cal} \\
\mathrm{mol}^{-1} \mathrm{~K}^{-1}\end{array}$ \\
\hline $6, \mathrm{X}=\mathrm{OTs}$ & $\begin{array}{l}95.2 \\
70.3 \\
49.9^{b} \\
25.0^{c}\end{array}$ & $\begin{array}{l}(5.0 \pm 0.1) \times 10^{-4} \\
(4.22 \pm 0.06) \times 10^{-5} \\
3.95 \times 10^{-6} \\
1.5 \times 10^{-7}\end{array}$ & 24.6 & -7.3 \\
\hline $\mathbf{1 3}, \mathrm{X}=\mathrm{OTs}$ & $\begin{array}{r}100.2 \\
95.1 \\
79.6 \\
25.0^{c}\end{array}$ & $\begin{array}{l}(3.87 \pm 0.15) \times 10^{-5} \\
(2.34 \pm 0.02) \times 10^{-5} \\
(4.05 \pm 0.18) \times 10^{-6} \\
2.2 \times 10^{-9}\end{array}$ & 28.1 & -3.9 \\
\hline 16, $\mathrm{X}=\mathrm{OTs}$ & $\begin{array}{l}95.1 \\
79.6 \\
25.0^{c}\end{array}$ & $\begin{array}{l}(2.10 \pm 0.01) \times 10^{-5} \\
(3.98 \pm 0.11) \times 10^{-6} \\
2.9 \times 10^{-9}\end{array}$ & 27.0 & -7.1 \\
\hline $18, X=0 T s$ & $\begin{array}{l}95.6^{d} \\
95.2 \\
25.0^{c}\end{array}$ & $\begin{array}{l}(4.13 \pm 0.06) \times 10^{-6} \\
(3.55 \pm 0.25) \times 10^{-6} \\
\text { ca. } 3 \times 10^{-10}\end{array}$ & $(28.6)$ & $(-6)^{e}$ \\
\hline
\end{tabular}

a Determined conductometrically in duplicate, except where stated otherwise; errors shown are average deviations. ${ }^{b}$ Single measurement of rate constant. ${ }^{\circ}$ Calculated from kinetic data at higher temperatures. ${ }^{d}$ Determined by HPLC from the rate of appearance of acid and the rate of disappearance of ester, normalized as described in ref 17 . e Assumed from three values above.

Table II. Rate Constants and Derived Parameters for Solvolyses of Tetramethylcyclopentyl Tosylate $(6, X=$ OTs) at $25.0^{\circ} \mathrm{C}^{a}$

\begin{tabular}{llrr}
\hline \multicolumn{1}{c}{ solvent } & rate constant $\left(\mathrm{s}^{-1}\right)$ & $\begin{array}{c}\log \\
\left(k / k_{0}\right)^{b}\end{array}$ & $Y_{\mathrm{OTs}^{c}}{ }^{c}$ \\
\hline acetic acid $^{d}$ & $8.1 \times 10^{-8}$ & -0.27 & -0.61 \\
$80 \% \mathrm{v} / \mathrm{v}$ ethanol $/$ water $^{e}$ & $1.5 \times 10^{-7}$ & 0.00 & 0.00 \\
$50 \% \mathrm{v} / \mathrm{v}$ ethanol $/$ water $^{f}$ & $(1.60 \pm 0.08) \times 10^{-6}$ & 1.03 & 1.29 \\
$97 \% \mathrm{w} / \mathrm{w}$ & $(9.3 @ 0.2) \times 10^{-6}$ & 1.79 & 1.83 \\
$\mathrm{CF}_{3} \mathrm{CH}_{2} \mathrm{OH} / \mathrm{H}_{2} \mathrm{O}$ & & & \\
$97 \% \mathrm{w} / \mathrm{w}$ & $(3.45 \pm 0.1) \times 10^{-4}$ & 3.36 & 3.61
\end{tabular}

\section{$\left(\mathrm{CF}_{3}\right)_{2} \mathrm{CHOH} / \mathrm{H}_{2} \mathrm{O}^{8}$}

${ }^{a}$ Determined conductometrically in duplicate, except where stated otherwise; errors shown are average deviations. ${ }^{b}$ Solvent effect on rate constant $(k)$ relative to $80 \%$ ethanol/water $\left(k_{0}\right)$. ${ }^{c}$ Scale of solvent ionization power; see ref $18 \mathrm{a} .{ }^{d}$ Extrapolated from literature data (ref 8) at 65 and $80^{\circ} \mathrm{C}$. ${ }^{e}$ Table I. Determined from a study of $50 \%$ reaction; the solution was then heated at 49.9 ${ }^{\circ} \mathrm{C}$ to obtain an infinity value, and by monitoring of this stage, a rate constant of $(3.91 \pm 0.01) \times 10^{-5}$ was obtained; hence $\Delta H^{*}=$ $24.0 \mathrm{kcal} / \mathrm{mol}$ and $\Delta S^{\ddagger}=-4.7 \mathrm{cal} \mathrm{mol}^{-1} \mathrm{~K}^{-1}$. ${ }^{8}$ Literature value: $3.67 \times 10^{-4} \mathrm{~s}^{-1}$ (ref 19).

diode-array detection does not provide accurate $\epsilon$ values, the $p$-toluenesulfonic acid coproduct provides an internal standard from which $\epsilon>10^{4}$ could be estimated for the triene 23. Similar solvolyses of the two cyclopentenyl tosylates $(13,18, \mathrm{X}=\mathrm{OTs})$ gave products having $\lambda_{\max }$ at $256 \mathrm{~nm}$, as observed in the buffered solvolyses (above). Cyclopentadiene has $\lambda_{\max }=238.5 \mathrm{~nm} ; 16 \mathrm{~b} 21$ and 22 have higher $\lambda_{\max }$ because of alkyl substitution. At longer reaction times, the diene 21 was converted into another product having $\lambda_{\max }=267 \mathrm{~nm}$, presumably formed by acid-catalyzed isomerization.

Kinetic Data. Rate constants for $80 \% \mathrm{v} / \mathrm{v}$ ethanol/ water mixtures are given in Table I. Solvent effects on the reactivity of tetramethylcyclopentyl tosylate 6 (X = OTs) confirmed that the methyl groups had reduced the $k_{\mathrm{s}}$ character of the solvolyses substantially (Table II).

\section{Discussion}

The solvent effects on the reactivity of tetramethylcyclopentyl tosylate (Table II) are similar to those observed for solvolyses of 2 -adamantyl tosylate $;^{18}$ correlating the

(17) Bentley, T. W.; Gream, G. E. J. Org. Chem. 1985, 50, 1776.
Table III. Correlations of Solvent Effects on Reactivity for Cyclopentyl (10), 2,2-Dimethylcyclopentyl (24), and 2,2,5,5-Tetramethylcyclopentyl (6) Tosylates

\begin{tabular}{llllc}
\hline \multicolumn{1}{c}{ tosylate } & \multicolumn{1}{c}{$Q^{\prime}($ eq 1) } & intercept & $\begin{array}{c}\text { std dev } \\
\text { in } \log k\end{array}$ & correl coeff \\
\hline 2-propyl & 0.0 (defined) $^{a}$ & & & \\
cyclopentyl & $0.30 \pm 0.03$ & $0.00 \pm 0.06$ & 0.14 & 0.995 \\
$\mathbf{2 4}^{b}$ & $0.73 \pm 0.05$ & $0.12 \pm 0.12$ & 0.16 & 0.995 \\
$\mathbf{6}^{c}$ & $0.94 \pm 0.09$ & $0.05 \pm 0.18$ & 0.27 & 0.991 \\
2-adamantyl & 1.0 (defined) & & &
\end{tabular}

${ }^{a}$ Reference $18 \mathrm{~b} .{ }^{b}$ Kinetic data from Table IV with an additional data point for $70 \% \mathrm{w} / \mathrm{w}$ trifluoroethanol/water (ref 20a). ${ }^{c}$ Kinetic data from Table II.

kinetic data by the $m Y_{\mathrm{OTs}_{\mathrm{s}}}$ equation ${ }^{18 \mathrm{~b}}$ gives an $m$ value of $0.88 \pm 0.06$ (intercept $0.11 \pm 0.11$, standard deviation in $\log k 0.18$, correlation coefficient 0.994 ) and a slightly more precise fit than that given by the $Q^{\prime}$ equation (eq 1 ) (Table III). ${ }^{18 \mathrm{~b}}$ Deviations from these equations indicate that the $\log \left(k / k_{0}\right)_{\mathrm{ROTs}}=$

$$
Q^{\prime} \log \left(k / k_{0}\right)_{2-\mathrm{AdOT}}+(1-Q) \log \left(k / k_{0}\right)_{2-\mathrm{PrOTs}}
$$

acetolysis rate constant for 6 ( $\mathrm{X}=\mathrm{OTs}$ ) is slightly greater than expected and the rate constant for $50 \%$ ethanol/ water is less than expected (see columns 3 and 4 of Table II). Despite these minor inconsistencies (possibly due to data from different sources), the results confirm that the nucleophilic solvent assistance $\left(k_{8}\right.$ character) for solvolyses of the tetramethylcyclopentyl substrates (e.g., $6, \mathrm{X}=\mathrm{OTs}$, $Q^{\prime}=0.94$, Table III) is much less than for solvolyses of cyclopentyl tosylate $\left(10, Q^{\prime}=0.30\right)$. This supports our expectation that the introduction of four $\beta$-methyl groups in the substrates $(6,13,16$, and 18$)$ results in either very weakly or nonnucleophilically assisted solvolyses.

All of the observed reaction products (19-23) might arise by 1,2-methyl shifts from the initially formed secondary carbocation ion pairs to give tertiary or allylic carbocations. Because such rearrangements are energetically favorable, this step and all other product-determining steps are probably rapid, so that the relative rates of solvolyses reflect rates of ionization. An alternative possibility is that methyl shifts accompany ionization ( $k_{\Delta}$ solvolysis); such reactions usually proceed with very small rate enhancements. ${ }^{21}$ For unsaturated systems $(13,16,18)$, an additional driving force for methyl shift $\left(k_{\Delta}\right)$ would be the formation of incipient allylic cations. An analogy is the rate enhancement observed in solvolyses of 7-syn-norbornenyl tosylate. ${ }^{7 \mathrm{C}}$ Such methyl participation (if present) would increase rates of solvolyses and would lead to underestimation of the rate-retarding effects of the double bond. In principle, from solvent effects on reactivity, it should be possible to distinguish between weak $k_{\mathrm{g}}$ and weak $k_{\Delta}$ processes, but this has not yet proved to be convincing in practice. ${ }^{18 \mathrm{~b}}$ Consequently we have not attempted a more detailed study of solvent effects in this work.

With the reduction or elimination of the complication of nucleophilic solvent participation during solvolyses of

(18) (a) Schadt, F. L.; Bentley, T. W.; Schleyer, P. v. R. J. Am. Chem. Soc. 1976, 98, 7667. (b) Bentley, T. W.; Bowen, C. T.; Morten, D. H.; Schleyer, P. v. R. J. Am. Chem. Soc. 1981, 103, 5466.

(19) Schneider, H.-J.; Becker, N.; Schmidt, G.; Thomas, F. J. Org. Chem. 1986, 51, 3602 .

(20) (a) Shiner, V. J., Jr.; Imhoff, M. A. J. Am. Chem. Soc. 1985, 107, 2121. (b) Seib, R. C.; Shiner, V. J., Jr.; Sendijarevič, V.; Humski, K. J. Am. Chem. Soc. 1978, 100, 8133. (c) Roberts, D. D. J. Org. Chem. 1968, 33,118 .

(21) (a) Ando, T.; Morisaki, H. Tetrahedron Lett. 1979, 121. (b) Shiner, V. J., Jr.; Seib, R. C. Tetrahedron Lett. 1979, 123. (c) Shiner, V. J., Jr.; Tai, J. J. Tetrahedron Lett. 1979, 127. (d) Bentley, T. W.; Liggero, S. H.; Imhoff, M. A.; Schleyer, P. v. R. J. Am. Chem. Soc. 1974, 96, 1970. 
cyclopentenyl (9) and cyclopentyl (10) tosylates by steric shielding of the reaction center, the carbocationic $\left(k_{c}\right)$ reactivity is revealed more clearly. Solvolyses of the corresponding tetramethyl-substituted systems $(6,18, \mathrm{X}=$ OTs) in $80 \%$ ethanol/water show a rate ratio of 1.00:0.0078 at $95^{\circ} \mathrm{C}$ and $1.00: 0.002$ at $25^{\circ} \mathrm{C}$ (Table I). These results $\left(\Delta \Delta G^{\ddagger}=3.7 \mathrm{kcal} / \mathrm{mol}\right.$ at $\left.25^{\circ} \mathrm{C}\right)$ are in qualitative agreemeni with ab initio molecular orbital calculations, which show that the planar conformer of the cyclopenten-4-yl cation (25) is $5-10 \mathrm{kcal} / \mathrm{mol}$ less stabilized than the cyclopentyl cation (26). ${ }^{9}$ Although these rate-retarding effects of the double bond are 10-50 times greater than expected from previous experimental studies (Scheme I), ${ }^{10}$ the large inductive effect of a CC double bond attached directly to a carbocation center is demonstrated by the $10^{4}$ rate retardation in the acetolysis of 2-methyleneadamantyl tosylate. ${ }^{22}$

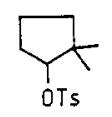

(24)

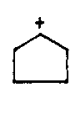

(26)

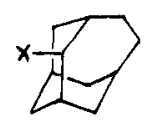

(29)

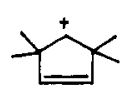

(27)

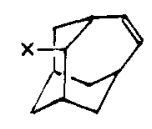

(28)
The calculations ${ }^{9}$ also predict that bishomoallylic participation (bridging) in the cyclopenten-4-yl cation (25) should be thermodynamically very favorable. However, bridging requires bending of the five-membered ring. In the tetramethyl derivative 18 , this will bring the $\beta$ - and $\beta^{\prime}$-methyl groups closer together and may inhibit $\pi$ participation. To examine this possibility, we carried out MINDO $/ 3^{23 \mathrm{a}}$ molecular orbital calculations starting with the planar classical cations 25 and 27. Barriers to bridging of similar size were predicted for both cations $(\mathbf{2 5}, \mathbf{2 7})$. Unfavorable nonbonded $\mathrm{CH}_{3} \ldots \mathrm{CH}_{3}$ interactions in the transition structure for 27 are reduced by methyl twisting and by angle widening. However, the MINDO $/ 3$ results may not be reliable because an energy difference of only $6.2 \mathrm{kcal} / \mathrm{mol}$ between the planar and bridged cyclopenten-4-yl cations 25 is predicted, ${ }^{23 b}$ whereas the best available value from ab initio calculations is over twice as large $(13 \mathrm{kcal} / \mathrm{mol}) .^{9}$ This implies that the ab initio barrier to bridging will be lower, and additional calculations necessary to clarify this matter are planned. Also, if the parent cation 25 has a substantial barrier to bridging, 1,2-hydride shifts should have been seen. ${ }^{24}$

Experimental data strongly suggest that large rate enhancements are observed in homoallylic systems only when the initial geometry is relatively inflexible and close to that required for bridging, ${ }^{6,7}$ e.g., solvolyses of 7-anti-norbornenyl derivatives $3^{7}$ and of 2-exo-homoadamant-4-enyl tosylate $(28, \mathrm{X}=\mathrm{OTs})$, which reacts $3 \times 10^{5}$ times faster than the corresponding saturated tosylate $(29, \mathrm{X}=\mathrm{OTs}) .^{6}$ The tendency for bridging to lag behind ionization ${ }^{9,25}$ may influence the reactivity of more flexible systems $(5,9,18)$, but this would be more difficult to study theoretically.

(22) Ree, B. R.; Martin, J. C. J. Am. Chem. Soc. 1970, 92, 1660. See also: Schleyer, P. v. R.; Buss, V. J. Am. Chem. Soc. 1969, 91, 5880.

(23) (a) Bingham, R. C.; Dewar, M. J. S.; Lo, D. H. J. Am. Chem. Soc. 1975, 97, 1294. (b) Houriet, R.; Schwarz, H.; Zummack, W.; Andrade, J. G.; Schleyer, P. v. R. Nouv. J. Chim. 1981, 5, 505.

(24) Saunders, M.; Chandrasekhar, J.; Schleyer, P. v. R. In Rearrangements in Ground and Excited States; De Mayo, P., Ed.; Academic: New York, 1980, Vol. 1, p 1.

(25) Winstein, S. J. Am. Chem. Soc. 1965, 87, 381.
Table IV. Relative Rates of Solvolyses of Cyclopentyl (CP, 10), 2,2-Dimethylcyclopentyl (DMC, 24), and

2,2,5,5-Tetramethylcyclopentyl (TMC, 6) (X = OTs) Tosylates at $25^{\circ} \mathrm{C}$

\begin{tabular}{lccc}
\hline \multicolumn{1}{c}{ solvent } & $10^{5} k_{\mathrm{CP}}, \mathrm{s}^{-1}$ & $k_{\mathrm{DMC}} / k_{\mathrm{CP}}{ }^{a}$ & $k_{\mathrm{TMC}} / k_{\mathrm{CP}}{ }^{b}$ \\
\hline $97 \%\left(\mathrm{CF}_{3}\right)_{2} \mathrm{CHOH} / \mathrm{H}_{2} \mathrm{O}$ & $30^{c}$ & $10.0^{d}$ & 1.15 \\
$97 \% \mathrm{CF}_{3} \mathrm{CH}_{2} \mathrm{OH} / \mathrm{H}_{2} \mathrm{O}$ & $3.5^{e}$ & 4.04 & 0.27 \\
$\mathrm{CH}_{3} \mathrm{CO}_{2} \mathrm{H}$ & $0.165^{f}$ & $0.86^{g}$ & $0.049^{h}$ \\
$80 \% \mathrm{EtOH} / \mathrm{H}_{2} \mathrm{O}$ & $2.91^{f}$ & 0.19 & 0.0052
\end{tabular}

${ }^{a}$ Kinetic data based on $p$-bromobenzenesulfonates from ref 20a. ${ }^{b}$ Kinetic data also from Table II. ' Reference 9; also $k=3.54 \times$ $10^{-4}$, ref $19 .{ }^{d}$ Rate ratio in $90 \%\left(\mathrm{CF}_{3}\right)_{2} \mathrm{CHOH} / \mathrm{H}_{2} \mathrm{O}$. ${ }^{e}$ Reference $20 \mathrm{~b}$, assuming a OBs/OTs rate ratio of 3 . ${ }^{\prime}$ Reference $20 \mathrm{c}$. ${ }^{8}$ Tosylates at $65^{\circ} \mathrm{C}$, ref $8 \mathrm{~b} .{ }^{h}$ Discussed in ref $8 \mathrm{a}$.

Table V. Strain Energies of Alcohols and Corresponding Ketones of Tetramethylcyclopentane Derivatives ${ }^{a}$

\begin{tabular}{lcccc}
\hline \multicolumn{1}{c}{ substrate } & $\mathbf{6}$ & $\mathbf{1 3}$ & $\mathbf{1 6}$ & $\mathbf{1 8}$ \\
\hline alcohol $(\mathrm{X}=\mathrm{OH})$ & 10.36 & 10.20 & 11.59 & 9.02 \\
ketone & 7.48 & 6.77 & 8.72 & 6.71 \\
(difference) & $(2.88)$ & $(3.43)$ & $(2.87)$ & $(2.31)$
\end{tabular}

${ }^{a}$ In $\mathrm{kcal} / \mathrm{mol}$. Determined by MM2 force field calculations; for method, see ref 27 .

If anchimeric assistance by the double bond were substantial, it would be revealed by methyl substitution on the double bond. Thus, the 7-anti-norbornenyl (3) systems exhibit a cumulative effect of methyl groups $\left(k_{\text {rel }} 1: 13: 148\right.$ for $\left.\mathrm{H}, \mathrm{H}: \mathrm{H}, \mathrm{CH}_{3}: \mathrm{CH}_{3}, \mathrm{CH}_{3}\right) ; 26$ in contrast, incorporation of two methyl groups in the tetramethylcyclopentenyl system 18 , giving 13 , leads only to a 6 -fold rate increase (Table I). This small effect may be due to electron donation by the methyl group. Alternatively, the small rate increase on methyl substitution $(\mathbf{1 8} \rightarrow \mathbf{1 3})$ may be explained by greater relief of strain in 13. Force-field calculations (Table V) show that the relief of strain in going from alcohol to the corresponding ketone is greatest for the hexamethylcyclopentenyl substrate 13 by over $1.1 \mathrm{kcal} / \mathrm{mol}$ more than for tetramethylcyclopentenyl 18. Similar strain-energy differences might be expected for solvolyses, because these also involve a change in hybridization at the reaction center from $\mathrm{sp}^{3}$ (approximated by the alcohol) to $\mathrm{sp}^{2}$ (approximated by the corresponding ketone)..$^{19,28}$

It could be argued that introduction of a double bond into a cyclopentyl ring may reduce torsional (I) strain, release of which during solvolyses accelerates saturated cyclopentyl substrates. ${ }^{86,29}$ However, these kinetic effects are not large. Force-field calculations (Table V) indicate very similar releases of strain energy for conversion of alcohols $(6,18, \mathrm{X}=\mathrm{OH})$ to the corresponding ketones. In $80 \%$ ethanol/water, 1-chloro-1-methylcyclopentane solvolyzes 15 times faster than $\mathrm{Et}_{2} \mathrm{MeCCl}$, an acyclic analogue. ${ }^{29}$ In weakly nucleophilic media $\left(\mathrm{CF}_{3} \mathrm{CH}_{2} \mathrm{OH}\right.$ and HFIP), cyclopentyl tosylate (10) reacts only 5 times faster than its acyclic analogue, 3-pentyl tosylate. ${ }^{18 \mathrm{~b}}$ Larger rate ratios were observed for cyclopentyl compared with cyclohexyl rings ( $>100$-fold for solvolyses of tertiary halides $^{29}$ ), but effects of similar magnitude $(50$-fold) were observed for electrophilic additions to exocyclic double bonds. ${ }^{30}$ In such reactions there should be no change in torsional strain because the ring carbon atom is $\mathrm{sp}^{2}$, both in the alkene starting material and in the carbocation intermediate. Hence the greater reactivity of five-mem-

(26) Gassman, P. G.; Patton, D. S. J. Am. Chem. Soc. 1969, 91, 2160. (27) Allinger, N. L. J. Am. Chem. Soc. 1977, 99, 8127. 1418 .

(28) Müller, P.; Blanc, J.; Perlberger, J.-C. Helv. Chim. Acta 1982, 65,

(29) Brown, H. C.; Borkowski, M. J. Am. Chem. Soc. 1952, 74, 1894.

(30) Mayr, H.; Pock, R. Chem. Ber. 1986, 119, 2473. 
bered rings appears to be associated only to a small extent with torsional strain. The behavior of the indanyl tosylate 5 also indicates that torsional effects in tetramethylcyclopentyl tosylates $(6, X=0 T s)$ are not significant. ${ }^{8 a}$

The similar solvolysis rates for the cyclopentenyl tosylates 13 and 18 (X = OTs) and the bis(methylene) substituted tosylate 16 ( $\mathrm{X}=\mathrm{OTs}$ ) demonstrate that bishomocyclopropenylium stabilization is not present in the transition states of the solvolysis reactions. No evidence for diene participation was found in the solvolysis of 2,3exo-bis(methylene)-anti-7-norbornyl sulfonate, in which only one of the double bonds appears to participate. ${ }^{31 a}$ Symmetry impedes a stabilizing interaction between the LUMO of the carbocation and the HOMO of the diene. ${ }^{31}$ However, even when this symmetry constraint was removed (e.g., for solvolyses of exo- and endo-5,6-bis(methylene)-2-norbornyl sulfonates), only weak diene participation was evident because rates of solvolyses closely resembled those of the corresponding 5-norbornenyl and benzo-5-norbornenyl sulfonates. ${ }^{31}$

Effects of Methyl Substitution on Solvolyses of Cyclopentyl Tosylate. Solvent effects on the reactivity of 2,2-dimethylcyclopentyl tosylate (24) fit the $Q^{\prime}$ equation well (Table III) and are consistent with a $k_{\mathrm{g}}$ solvolysis. Introduction of only two methyl groups is insufficient to prevent nucleophilic solvent assistance completely, in contrast to the interpretation given recently. ${ }^{20 a}$ Hence structural effects on reactivity will be considered only for weakly nucleophilic solvents, HFIP and trifluoroacetic acid. 18,19

Trifluoroacetolysis of trans-2-methylcyclopentyl tosylate is 2.6 times faster than that of cyclopentyl tosylate (10); $; 2$ in $97 \%$ HFIP/water, the rate ratio is 2.1 . $^{19 a}$ The effect of a second methyl group is approximately cumulative because, in $90 \%$ HFIP/water, 2,2-dimethylcyclopentyl tosylate (24) reacts 10 times faster than cyclopentyl (Table IV). These effects are within the range expected for inductive/hyperconjugative effects. ${ }^{33}$ Although larger effects are observed in acyclic systems, the effects are still cumulative, ${ }^{21 d}$ showing no detectable effects of changing the electron demand.

The low reactivity of tetramethylcyclopentyl tosylate 6 $(\mathrm{X}=\mathrm{OTs}$ ) relative to cyclopentyl tosylate is partly due to nucleophilic solvent assistance for solvolyses of cyclopentyl tosylate in acetic acid ${ }^{8 a}$ and in $80 \%$ ethanol/water (Table IV). However, even in HFIP, the solvolysis rate of $6(\mathrm{X}=\mathrm{OTs})$ is about the same as for cyclopentyl tosylate (Table IV); this can be compared with a prediction of 100 times faster than cyclopentyl, based on the expected cumulative electronic effect of methyl substitution (see above). An additional rate acceleration of steric origin (relief of "B-strain") might also have been expected ${ }^{34 a}$ (this partially explains why solvolyses of di-tert-butylcarbinyl tosylate in $97 \%$ trifluoroethanol/water are 630 times faster than those of 2-propyl tosylate ${ }^{34 b}$ ). Also cis-2-methylcyclopentyl tosylate reacts 19 times faster than cyclopentyl tosylate in $97 \% \mathrm{HFIP} /$ water, in good agreement with MM2 force-field calculations; ${ }^{19}$ this agreement may be fortuitous because of the possibility of 1,2-hydride par-

(31) (a) Tsuji, T.; Ishitobi, H.; Tanida, H. Tetrahedron Lett. 1972 3083. (b) Sonney, J.-M.; Vogel, P.; Burger, U. Helv. Chim. Acta 1980, 63, 1016 .

(32) Nordlander, J. E.; Gruetzmacher, R. R.; Kelley, W. J.; Jindal, S. P. J. Am. Chem. Soc. 1974, 96, 181.

(33) Bentley, T. W. Annu, Rep. Prog. Chem., Sect. B 1974, 71, 120 (34) (a) Brown, H. C.; Ichikawa, K. J. Am. Chem. Soc. 1962, 84, 373 (b) Liggero, S. H.; Harper, J. J.; Schleyer, P. v. R.; Krapcho, A. P.; Horn, D. E. J. Am. Chem. Soc. 1970, 92, 3789. See also: Olah, G. A.; Prakash, G. K. S.; Liang, G.; Schleyer, P. v. R.; Graham, W. D. J. Org. Chem. 1982, 47,1040 . ticipation, although observed rate enhancements (e.g., in solvolyses of 3-methyl-2-butyl sulfonates) are small even when the conformations are favorable. ${ }^{35}$

While we have estimated only electronic effects, both electronic and steric effects should contribute. Schneider et al. ${ }^{19}$ calculated changes of strain energy. Both considerations support the conclusion that $6(\mathrm{X}=\mathrm{OTs})$ reacts anomalously slowly. If both electronic and strain-energy effects were to be calculated together, it seems likely that the reactivity of 6 ( $\mathrm{X}=$ OTs) would be predicted to be even lower.

The low reactivity of tetramethylcyclopentyl tosylate 6 $(\mathrm{X}=\mathrm{OTs}$ ) can also be attributed to steric inhibition of leaving-group solvation, ${ }^{8,33}$ an alternative interpretation of Brown's steric hindrance to ionization. ${ }^{36}$ Recently this controversial proposal has been supported strongly by force-field calculations on many secondary substrates including 6 and 8. ${ }^{19}$ Both 2,2-dimethyl- and 2,2,5,5-tetramethylcyclopentanes (24 and 6) are similar to 2-endonorbornyl tosylate $(8, \mathrm{X}=\mathrm{OTs})$ in having crowded environments. Early attempts to provide independent support for a steric effect were unsuccessful, ${ }^{37}$ and as yet, there is no general agreement. ${ }^{38}$

Rate retardations have also been observed in solvolyses of 3,3-dimethyl-2-endo-norbornyl and isofenchyl sulfonates, structurally related to 6 with respectively three and four alkyl groups in the $\beta$-position of a cyclopentanol derivative. ${ }^{19}$ For example, acetolyses were about 8 times slower than that of the parent 2-endo-norbornyl sulfonate $8(\mathrm{X}=\mathrm{OBs})$, and opposing steric and inductive effects were noted. ${ }^{39}$ In $97 \%$ HFIP, the 3,3-dimethyl derivative reacts about half as fast as 2-endo-norbornyl tosylate (8, $\mathrm{X}=\mathrm{OTs}$ ). ${ }^{19}$ Allowing a rate acceleration of 10 for the 3,3-dimethyl substituents (see above), a corrected rate retardation of about 20 due to steric effects can now be estimated; this is in addition to a steric effect (if any) operating in 8 ( $\mathrm{X}=\mathrm{OBs}$ ). As no 1,2-methyl shifts were observed, the results cannot be explained by rate-limiting methyl migration as proposed previously for solvolyses of $24(\mathrm{X}=\mathrm{OBs}){ }^{20 \mathrm{a}}$

In summary, solvent and structural effects (Tables III and IV) on the reactivity of cyclopentyl tosylate (10) and its $\beta$-methyl derivatives can be attributed to changes in susceptibility to nucleophilic solvation, to inductive/hyperconjugative effects on alkyl substitution and to steric effects (strain relief on ionization and inhibition of solvation of the leaving group). Each effect could contribute about 100 -fold to the relative rates (Table IV). In contrast, detailed studies of two of these cyclopentyl sulfonates $\left(10^{20 \mathrm{~b}}\right.$ and $\left.24^{20 \mathrm{a}}\right)$ employed an alternative method of data analysis, ${ }^{20 a}$ which emphasized the small and controversial ${ }^{18 a, 21 d}$ effects of internal ion pair return. Although well established, the influence of nucleophilic solvent assistance to ionization was not accepted, ${ }^{20 \mathrm{a}, \mathrm{b}}$ and no satisfactory overall interpretation of the kinetic data (Table IV) was achieved.

\section{Conclusion}

The tetramethylcyclopentenyl sulfonate 18 (X = OTs) solvolyzes with very weak (if any) nucleophilic solvent assistance and with weak (if any) anchimeric assistance.

(35) Winstein, S.; Takahashi, J. Tetrahedron 1958, 2, 316.

(36) Brown, H. C.; Vander Jagt, D. L.; Rothberg, I.; Hammar, W. J.; Kawakami, J. H. J. Org. Chem. 1985, 50, 2179.

(37) Menger, F. M.; Thanos, T. E. J. Am. Chem. Soc. 1976, 98, 3267.

(38) Müller, P.; Mareda, J. Helv. Chim. Acta 1987, 70, 1017.

(39) Colter, A.; Friedrich, E. C.; Holness, N. J.; Winstein, S. J. Am. Chem. Soc. 1965, 87, 378 . 
Comparison with the reactivity of the saturated analogue 6 reveals the large rate-retarding effect of the remote double bond (500-fold in $80 \%$ ethanol/water at $25^{\circ} \mathrm{C}$ ), consistent with ab initio molecular orbital calculations. ${ }^{9}$ These effects are observed experimentally because participation of the $\mathrm{C}=\mathrm{C}$ neighboring group is prevented or inhibited by strain and steric effects. Neighboring-group participation by other electronegative groups having larger inductive effects ${ }^{2,40}$ may have to overcome even larger rate-retarding effects before a net rate enhancement can be observed. Alleged "homoaromatic effects" can also be rationalized by large inductive and hyperconjugative effects ${ }^{41}$ rather than by homoconjugation. Alkyl substitution in 6 (and probably also in 13, 16, and 18) leads to anomalously low rates of solvolyses (X $=\mathrm{OTs}$ ), probably because of steric hindrance to solvation and to departure of the leaving group..$^{19,33,36}$

\section{Experimental Section}

2,2,3,4,5,5-Hexamethylcyclopent-3-en-1-ol (13, $\mathrm{X}=\mathrm{OH})$. $\mathrm{TiCl}_{4}(3.95 \mathrm{~g}, 20.8 \mathrm{mmol})$ was dissolved in $70 \mathrm{~mL}$ of dry $\mathrm{CH}_{2} \mathrm{Cl}_{2}$ at $-78^{\circ} \mathrm{C}$ (nitrogen atmosphere). A solution of the allylic chlorides $11 \mathrm{a}, \mathbf{b}^{12 \mathrm{c}}(2.12 \mathrm{~g}, 16.0 \mathrm{mmol})$ and of $12^{42}(2.30 \mathrm{~g}, 16.0 \mathrm{mmol})$ in 30 $\mathrm{mL}$ of $\mathrm{CH}_{2} \mathrm{Cl}_{2}$ was added dropwise with stirring. The deep red solution was stirred at $-78^{\circ} \mathrm{C}$ for $3 \mathrm{~h}$ and then slowly poured into $50 \mathrm{~mL}$ of $5 \%$ aqueous ammonium carbonate solution. The aqueous layer was extracted with two $20-\mathrm{mL}$ portions of $\mathrm{CH}_{2} \mathrm{Cl}_{2}$, and the combined organic layers were dried with $\mathrm{Na}_{2} \mathrm{SO}_{4}$. The solvents were evaporated to give a dark brown residue, which was distilled to yield $14(0.67 \mathrm{~g}, 25 \%)$ with bp $35-40{ }^{\circ} \mathrm{C}$ (bath) $/ 1$ mbar. ${ }^{12 \mathrm{~b}}$ Compound $13(\mathrm{X}=\mathrm{OH})(1.75 \mathrm{~g}, 65 \%)$ was obtained from the residue by distillation at $35-40^{\circ} \mathrm{C}$ (bath) $/ 0.1$ mbar: ${ }^{1} \mathrm{H}$ $\operatorname{NMR}\left(\mathrm{CDCl}_{3}\right) \delta 0.92(\mathrm{~s}, 6 \mathrm{H}), 1.03(\mathrm{~s}, 6 \mathrm{H}), 1.51(\mathrm{~s}, 6 \mathrm{H}), 3.50(\mathrm{br}$ $\mathrm{s}, 1 \mathrm{H}) ;{ }^{13} \mathrm{C} \mathrm{NMR}\left(\mathrm{CDCl}_{3}\right) \delta 9.79$ (q), 20.34 (q), 27.26 (q), 47.30 (s), 87.78 (d), 134.86 (s)

2,2,4,5,5-Pentamethyl-3-(bromomethyl)cyclopent-3-en-1-ol (15). Dry $\mathrm{ZnBr}_{2}(334 \mathrm{mg}, 1.49 \mathrm{mmol})$ was added to a solution of $13(\mathrm{X}=\mathrm{OH} ; 1.00 \mathrm{~g}, 5.94 \mathrm{mmol})$ in $20 \mathrm{~mL}$ of $\mathrm{CHCl}_{3}$. At ambient temperature, $3.5 \mathrm{~mL}$ of a $2 \mathrm{M}$ solution of $\mathrm{Br}_{2}$ in $\mathrm{CHCl}_{3}$ was added dropwise with stirring. After $1 \mathrm{~h}$, the mixture was washed with $20 \mathrm{~mL}$ of saturated aqueous sodium bisulfite solution and dried with $\mathrm{Na}_{2} \mathrm{SO}_{4}$. Distillation gave $1.10 \mathrm{~g}(75 \%)$ of 15 : bp $30-40^{\circ} \mathrm{C}$ (bath) $/ 5 \times 10^{-4} \mathrm{mbar} ;{ }^{1} \mathrm{H}$ NMR $\left(\mathrm{CDCl}_{3}\right) \delta 0.92(\mathrm{~s}, 3 \mathrm{H}), 1.00(\mathrm{~s}$, $3 \mathrm{H}), 1.02(\mathrm{~s}, 3 \mathrm{H}), 1.12(\mathrm{~s}, 3 \mathrm{H}), 1.58(\mathrm{~s}, 3 \mathrm{H}), 3.48(\mathrm{~s}, 1 \mathrm{H}), 3.94$ (s, $2 \mathrm{H}$ ), $\mathrm{OH}$ masked.

2,2,5,5-Tetramethyl-3,4-bis(methylene)cyclopentan-1-ol (16, $\mathbf{X}=\mathbf{O H})$. Compound $15(3.90 \mathrm{~g}, 15.8 \mathrm{mmol})$ and triethylamine $(17.6 \mathrm{~g}, 174 \mathrm{mmol}$ ) were dissolved in $30 \mathrm{~mL}$ of benzene and heated at reflux for $26 \mathrm{~h}$. The mixture was cooled and filtered and the solvent evaporated $\left(30 \mathrm{mbar}, 40^{\circ} \mathrm{C}\right)$. Distillation of the dark yellow residue at $30-40{ }^{\circ} \mathrm{C}$ (bath) $/ 0.05 \mathrm{mbar}$ gave $1.05 \mathrm{~g}(40 \%)$ of $16(\mathrm{X}=\mathrm{OH})$, which crystallized in the freezer: $\mathrm{mp} \simeq 15^{\circ} \mathrm{C}$; ${ }^{1} \mathrm{H} \mathrm{NMR}\left(\mathrm{CDCl}_{3}\right) \delta 1.03(\mathrm{~s}, 6 \mathrm{H}), 1.13(\mathrm{~s}, 6 \mathrm{H}), 3.43(\mathrm{br} \mathrm{s}, 1 \mathrm{H})$, $4.80(\mathrm{~s}, 1 \mathrm{H}$, vinyl $\mathrm{H}), 5.37(\mathrm{~s}, 1 \mathrm{H}$, vinyl $\mathrm{H}), \mathrm{OH}$ masked.

2,2,3,4,5-Pentamethyl-4-hexen-1-al (17). $\mathrm{ZnCl}_{2}(5 \mathrm{~g})$ was dissolved in $6 \mathrm{~mL}$ of ether and $10 \mathrm{~mL}$ of $\mathrm{CH}_{2} \mathrm{Cl}_{2},{ }^{43}$ and $0.67 \mathrm{~mL}$ of this solution was diluted with $30 \mathrm{~mL}$ of cold $\left(-78^{\circ} \mathrm{C}\right) \mathrm{CH}_{2} \mathrm{Cl}_{2}$. Compounds 11a,b $(1.33 \mathrm{~g}, 10 \mathrm{mmol})$ and $12(1.44 \mathrm{~g}, 10 \mathrm{mmol})$ were dissolved in $20 \mathrm{~mL}$ of $\mathrm{CH}_{2} \mathrm{Cl}_{2}$ and added dropwise within $30 \mathrm{~min}$ to the cooled $\left(-78^{\circ} \mathrm{C}\right) \mathrm{ZnCl}_{2}$ solution. After being stirred at -78 ${ }^{\circ} \mathrm{C}$ for $2 \mathrm{~h}$, the solution was separated from the catalyst by washing with $25 \mathrm{~mL}$ of $25 \%$ aqueous ammonia. The aqueous layer was extracted with two $20-\mathrm{mL}$ portions of $\mathrm{CH}_{2} \mathrm{Cl}_{2}$, and the combined organic layers were dried with $\mathrm{Na}_{2} \mathrm{SO}_{4}$. Distillation $\left(45-50{ }^{\circ} \mathrm{C} / 0.05\right.$ mbar) gave $1.1 \mathrm{~g}(65 \%)$ of the aldehyde 17: ${ }^{1} \mathrm{H}$ NMR $\left(\mathrm{CDCl}_{3}\right)$ $\delta 0.90(\mathrm{~d}, J=7 \mathrm{~Hz}, 3 \mathrm{H}), 0.95(\mathrm{~s}, 6 \mathrm{H}), 1.44,1.57,1.61(3 \mathrm{br} \mathrm{s}$,

(40) Grob, C. A.; Schaub, B.; Schlageter, M. G. Helv. Chim. Acta 1980, $63,57$.

(41) Schleyer, P. v. R.; Kaufmann, E.; Kos, A. J.; Mayr, H.; Chandrasekhar, J. J. Chem. Soc., Chem. Commun. 1986, 1583 .

(42) House, H. O.; Czuba, L. Z.; Gall, M.; Olmstead, H. D. J. Org. Chem. 1969, 34, 2324.

(43) Mayr, H.; Striepe, W. J. Org. Chem. 1985, 50, 2995.
$9 \mathrm{H}), 2.90(\mathrm{q}, J=7 \mathrm{~Hz}, 1 \mathrm{H}), 9.41(\mathrm{~s}, 1 \mathrm{H}) ; \mathrm{IR} \nu_{\max } 2955,1702 \mathrm{~cm}^{-1}$. Alcohols 6 and $18(\mathrm{X}=\mathrm{OH})$ were prepared by $\mathrm{LiAlH}_{4}$ reduction of 2,2,5,5-tetramethylcyclopentan-1-one $^{44}$ and 2,2,5,5-tetramethylcyclopent-3-en-1-one ${ }^{45}$ respectively and were converted into the tosylates $(\mathrm{X}=\mathrm{OTs})$ by treatment with pyridine/toluenesulfonyl chloride. Compounds 13 and $16(\mathrm{X}=\mathrm{OH})$ were converted into the lithium alcoholates with MeLi in ether and then stirred with toluenesulfonyl chloride in ether for $3 \mathrm{~h}$ at ambient temperature.

Physical and spectroscopic data of the tosylates 6, 13, 16, and $18(\mathrm{X}=\mathrm{OTs})$ follow.

2,2,5,5-Tetramethylcyclopent-1-yl $p$-toluenesulfonate $(6$, $\mathbf{X}=$ OTs): IR (KBr) $\nu_{\max } 2953,2856,1596,1493,1463,1384,1365$, $1352,1350,1261,1188,1174,1094,1037,1018,972,961,873,862$, $818,670 \mathrm{~cm}^{-1} ;{ }^{1} \mathrm{H}$ NMR $\left(200 \mathrm{MHz}, \mathrm{CDCl}_{3} \delta 0.91,0.94(2 \mathrm{~s}, 12 \mathrm{H}\right.$, $\left.2,5-\mathrm{CH}_{3}\right), 1.38-1.57(\mathrm{~m}, 4 \mathrm{H}, 3,4-\mathrm{H}), 2.45\left(\mathrm{~s}, 3 \mathrm{H}, p-\mathrm{CH}_{3}\right), 4.12(\mathrm{~s}$, $1 \mathrm{H}, 1-\mathrm{H}), 7.34,7.82\left(\mathrm{AA}^{\prime}-\mathrm{BB}^{\prime}, J_{\mathrm{AB}}=8.3 \mathrm{~Hz}, 4 \mathrm{H}\right.$, aromatic $\left.\mathrm{H}\right)$; ${ }^{13} \mathrm{C} \mathrm{NMR}\left(\mathrm{CDCl}_{3}\right) \delta 21.64\left(\mathrm{q}, p-\mathrm{CH}_{3}\right), 23.94,29.05\left(2 \mathrm{q}, 2,5-\mathrm{CH}_{3}\right)$, $37.63(\mathrm{t}, \mathrm{C}-3,4), 42.05$ (s, C-2,5), 97.22 (d, C-1), 127.89 (d, $\mathrm{C}_{\mathrm{o}}$ ), 129.62 $\left(\mathrm{d}, \mathrm{C}_{\mathrm{m}}\right), 134.48\left(\mathrm{~s}, \mathrm{C}_{\mathrm{p}}\right), 144.46\left(\mathrm{~s}, \mathrm{C}_{\mathrm{i}}\right)$; MS $(70 \mathrm{eV}), \mathrm{m} / \mathrm{z} 296\left(\mathrm{M}^{+}\right.$, 1.2), 155 (15), $124(100), 109(20), 91(29), 81(7) ; \mathrm{mp} \mathrm{95-96}{ }^{\circ} \mathrm{C}$ (lit. ${ }^{8} \mathrm{mp} 95-96.5^{\circ} \mathrm{C}$ ). Anal. Calcd for $\mathrm{C}_{16} \mathrm{H}_{24} \mathrm{SO}_{3}: \mathrm{C}, 64.81 ; \mathrm{H}$, 8.17. Found: C, $64.7 ; \mathrm{H}, 8.4$.

$2,2,3,4,5,5$-Hexamethylcyclopent-3-en-1-yl p-toluenesulfonate (13, $\mathbf{X}=\mathbf{O T s})$ : IR ( $\mathrm{KBr}) \nu_{\max } 2960,2926,2863,1596$, 1493, 1461, 1444, 1384, 1362, 1352, 1189, 1174, 1094, 971, 874, 819, $682,665 \mathrm{~cm}^{-1} ;{ }^{1} \mathrm{H}$ NMR $\left(200 \mathrm{MHz}, \mathrm{CDCl}_{3}\right) \delta 0.90,0.93(2 \mathrm{~s}, 12$ $\left.\mathrm{H}, 2,5-\mathrm{CH}_{3}\right), 1.47\left(\mathrm{~s}, 6 \mathrm{H}, 3,4-\mathrm{CH}_{3}\right), 2.45\left(\mathrm{~s}, 3 \mathrm{H}, p-\mathrm{CH}_{3}\right), 4.44(\mathrm{~s}$, $1 \mathrm{H}, 1-\mathrm{H}), 7.35,7.85\left(\mathrm{AA}^{\prime}-\mathrm{BB}^{\prime}, J_{\mathrm{AB}}=8.5 \mathrm{~Hz}, 4 \mathrm{H}\right.$, aromatic $\left.\mathrm{H}\right)$; ${ }^{13} \mathrm{C} \mathrm{NMR}\left(\mathrm{CDCl}_{3}\right) \delta 9.76\left(\mathrm{q}, 3,4-\mathrm{CH}_{3}\right), 21.54\left(\mathrm{q}, 2,5-\mathrm{CH}_{3}\right), 21.64$ (q, $\left.p-\mathrm{CH}_{3}\right), 26.57\left(\mathrm{q}, 2,5-\mathrm{CH}_{3}\right), 47.43(\mathrm{~s}, \mathrm{C}-2,5), 95.93(\mathrm{~d}, \mathrm{C}-1), 127.86$ $\left(\mathrm{d}, \mathrm{C}_{\mathrm{o}}\right), 129.64\left(\mathrm{~d}, \mathrm{C}_{\mathrm{m}}\right), 134.19$ (s, C-3,4), $134.59\left(\mathrm{~s}, \mathrm{C}_{\mathrm{p}}\right), 144.40$ (s, $\mathrm{C}_{\mathrm{i}}$ ); MS $(70 \mathrm{eV}), \mathrm{m} / z 322\left(\mathrm{M}^{+}, 9\right), 307(5), 155(18), 135(100)$, 91 (33); $\mathrm{mp} 117-118^{\circ} \mathrm{C}$. Anal. Calcd for $\mathrm{C}_{18} \mathrm{H}_{26} \mathrm{SO}_{3}$ : C, 67.03; H, 8.13. Found: C, $67.3 ; \mathrm{H}, 8.1$.

2,2,5,5-Tetramethyl-3,4-bis(methylene)cyclopent-1-yl ptoluenesulfonate $(16, \mathbf{X}=\mathbf{O T s}): \mathbb{R}(\mathrm{KBr}) \nu_{\max } 2959,2920,2869$, $1661,1624,1597,1493,1464,1450,1399,1386,1353,1307,1291$, $1260,1210,1188,1173,1095,1053,1017,973,869,849,815,748$, $718,670 \mathrm{~cm}^{-1}$; ${ }^{1} \mathrm{H}$ NMR $\left(200 \mathrm{MHz}, \mathrm{CDCl}_{3}\right) \delta 1.04,1.06(2 \mathrm{~s}, 12$ $\left.\mathrm{H}, 2,5-\mathrm{CH}_{3}\right), 2.45\left(\mathrm{~s}, 3 \mathrm{H}, p-\mathrm{CH}_{3}\right), 4.37(\mathrm{~s}, 1 \mathrm{H}, 1-\mathrm{H}), 4.79(\mathrm{~s}, 2 \mathrm{H}$, vinyl $\mathrm{H}), 5.35(\mathrm{~s} ; 2 \mathrm{H}$, vinyl $\mathrm{H}), 7.34,7.82\left(\mathrm{AA}^{\prime}-\mathrm{BB}^{\prime}, J_{\mathrm{AB}}=8.4\right.$ $\mathrm{Hz}, 4 \mathrm{H}$, aromatic $\mathrm{H}) ;{ }^{13} \mathrm{C} \mathrm{NMR}\left(\mathrm{CDCl}_{3}\right) \delta 20.64\left(\mathrm{q}, \mathrm{p}-\mathrm{CH}_{3}\right), 23.83$, 27.15 (2 q, 2,5- $\mathrm{CH}_{3}$ ), 42.95 (s, C-2,5), 94.09 (d, C-1), 103.88 (t, methylene $\left.\mathrm{CH}_{2}\right), 126.80\left(\mathrm{~d}, \mathrm{C}_{\mathrm{o}}\right), 128.71\left(\mathrm{~d}, \mathrm{C}_{\mathrm{m}}\right), 133.20\left(\mathrm{~s}, \mathrm{C}_{\mathrm{p}}\right)$, $143.65\left(\mathrm{~s}, \mathrm{C}_{\mathrm{j}}\right), 153.65(\mathrm{~s}, \mathrm{C}-3,4)$ ) MS $(70 \mathrm{eV}), \mathrm{m} / \boldsymbol{z} 320\left(\mathrm{M}^{+}, 2\right), 155$ (13), 148 (100), $133(92), 91(28) ; \mathrm{mp} 79-80^{\circ} \mathrm{C}$.

2,2,5,5-Tetramethylcyclopent-3-en-1-yl p-toluenesulfonate (18, X = OTs): IR (KBr) $\nu_{\max } 2954,2922,1595,1464,1363,1351$, $1260,1189,1176,1095,1033,1018,981,963,882,869,847,819$, $801,761 \mathrm{~cm}^{-1} ;{ }^{1} \mathrm{H}$ NMR $\left(200 \mathrm{MHz}, \mathrm{CDCl}_{3}\right) \delta 0.95,1.00(2 \mathrm{~s}, 12$ $\left.\mathrm{H}, 2,5-\mathrm{CH}_{3}\right), 2.45\left(\mathrm{~s}, 3 \mathrm{H}, p-\mathrm{CH}_{3}\right), 4.37(\mathrm{~s}, 1 \mathrm{H}, 1-\mathrm{H}), 5.31(\mathrm{~s}, 2 \mathrm{H}$, $3,4-\mathrm{H}), 7.34,7.83\left(\mathrm{AA}^{\prime}-\mathrm{BB}^{\prime}, J_{\mathrm{AB}}=8.5 \mathrm{~Hz}, 4 \mathrm{H}\right.$, aromatic $\left.\mathrm{H}\right) ;{ }^{13} \mathrm{C}$ NMR $\left(\mathrm{CDCl}_{3}\right) \delta 21.65\left(\mathrm{q}, p-\mathrm{CH}_{3}\right), 23.84,28.35\left(2 \mathrm{q}, 2,5-\mathrm{CH}_{3}\right), 47.67$ (s, C-2,5), 94.96 (d, C-1), 127.91 (d, C $), 129.69$ (d, C m $_{\mathrm{m}}$ ), 134.22 (s, $\left.\mathrm{C}_{\mathrm{p}}\right), 136.18(\mathrm{~d}, \mathrm{C}-3,4), 144.60\left(\mathrm{~s}, \mathrm{C}_{\mathrm{i}}\right)$; MS $(70 \mathrm{eV}), \mathrm{m} / z 294\left(\mathrm{M}^{+}\right.$, 7), 155 (12), 139 (40), 123 (100), 111 (22), 107 (23), 97 (15), 91 (43), $69(48), 55(30), 43(43) ; \mathrm{mp} 89-90^{\circ} \mathrm{C}$. Anal. Calcd for $\mathrm{C}_{16} \mathrm{H}_{22} \mathrm{SO}_{3}$ : C, $65.25 ; \mathrm{H}, 7.48$. Found: C, $64.9 ; \mathrm{H}, 7.6$.

Kinetic Methods. Conductometric rate constants for $80 \%$ ethanol/water were obtained by using ca. $10 \mathrm{~mL}$ of $10^{-3} \mathrm{M}$ solution in sealed conductivity cells having bright platinum electrodes and robust tungsten/glass seals. ${ }^{46}$ Changes in conductance were monitored with a Wayne Kerr B331 autobalance conductance bridge, and rate constants were obtained by using the LSKIN computer program. ${ }^{47}$ For kinetic data at $25^{\circ} \mathrm{C}$, a cell having platinum electrodes and platinum/glass seals was used. Changes

(44) Lissel, M.; Neumann, B.; Schmidt, S. Liebigs Ann. Chem. 1987, 263.

(45) (a) Cullen, E. R.; Guziec, F. S.; Murphy, C. J. J. Org. Chem. 1982, 47, 3563. (b) Adam, W.; Berkessel, A.; Krimm, S. J. Am. Chem. Soc. 1986, 108,4556 .

(46) Bowen, C. T. Ph.D. Thesis, University of Wales, 1980.

(47) DeTar, D. F. In Computer Programs for Chemistry; Benjamin: New York, 1968; Vol. 1, pp 126-173. 
in conductance were monitored by a conductance amplifier, constructed by using metal-film resistors to provide more stable readings when ambient temperatures varied overnight during long kinetic runs. The amplifier was connected to a SOLARTRON 7151 computing multimeter, which collected and stored readings at set times. Extensive use of ultrasonics was made prior to all of the kinetic runs to try to ensure that molecular aggregates were broken up.

The kinetic run by high-performance liquid chromatography (reversed phase) was carried out by direct analysis of reaction solutions using the equipment and the method described earlier, ${ }^{17}$ in which the disappearance of starting material and appearance of product were monitored simultaneously. The chromatography column $(15 \mathrm{~cm} \times 1 / 4$ in.) was packed with $5-\mu \mathrm{m}$ SPHERISORB ODS2, and results were obtained by eluting with $90 \%(\mathrm{v} / \mathrm{v})$ methanol/water (flow rate $1 \mathrm{~mL} / \mathrm{min}, \lambda=263 \mathrm{~nm}$, volume of sample injected $15.0 \mu \mathrm{L}$ ).

Products. The diode-array system was an LKB rapid spectral detector Model 2140 (with the LKB 2140-202 Wavescan software package for the IBM PC), connected to the LDC HPLC system described earlier. ${ }^{48}$ Some solutions were studied at a single wavelength $(\lambda=263 \mathrm{~nm})$ directly after conductometric rate

(48) Bentley, T. W.; Freeman, A. E. J. Chem. Soc., Perkin Trans. 2 1984,1115 measurements $\left(<10^{-3} \mathrm{M}\right)$ had been completed, but for others, separate measurements in sealed ampules were made (ca. $2 \times 10^{-3}$ M).

Calculations. MINDO $/ 3^{23 \mathrm{a}}$ and $\mathrm{MM} 2^{27}$ calculations were carried out by standard methods.

Acknowledgment. We are grateful to G. Llewellyn for technical assistance with the kinetic studies, to D. S. Jones for improving the temperature stability of the conductance amplifier, to M. S. Garley for providing computer control for the 7151 computing multimeter, and to $\mathrm{M}$. Bremer (Erlangen) for the MINDO/3 calculations. We also thank SERC for financial support for HPLC equipment (T.W.B.) and the British Council for a Senior Fellowship (H.M.). The work at Erlangen and Lübeck was supported by the Fonds der Chemischen Industrie.

Registry No. $6(\mathrm{X}=\mathrm{OTs}), 15587-83-4 ; 6(\mathrm{X}=\mathrm{OH}), 15231$ 50-2; 6 (ketone), 4541-35-9; 11a, 79816-89-0; 11b, 114583-33-4; 12, $6651-34-9 ; 13$ (X = OTs), 114583-27-6; $13(\mathrm{X}=\mathrm{OH}), 114583-32-3$; 13 (ketone), 114583-39-0; 14, 114583-34-5; 15, 114583-35-6; 16 (X $=\mathrm{OTs}), 114583-28-7 ; 16(\mathrm{X}=\mathrm{OH}), 114583-36-7 ; 16$ (ketone), $114583-40-3 ; 17,114583-37-8 ; 18$ (X = OTs), 114583-29-8; 18 (X $=\mathrm{OH}), 114583-38-9 ; 18$ (ketone), 81396-36-3; 19, 65378-75-8; 20 , $114583-30-1 ; 21,4249-12-1 ; 22,4087-50-7 ; 23,103647-19-4$.

\title{
Gas-Phase Basicity of Olefinic $\mathrm{C}_{5}$ and $\mathrm{C}_{6}$ Carbonyl Compounds
}

\author{
G. Bouchoux,,$^{*}$, F. Djazi, ${ }^{\dagger}$ R. Houriet, ${ }^{\ddagger}$ and E. Rolli ${ }^{\ddagger}$ \\ DCMR-Ecole Polytechnique, 91128 Palaiseau Cedex, France, and EPFL-Institut de Chimie Physique, \\ CH-1015 Lausanne, Switzerland
}

Received November 5, 1987

\begin{abstract}
Determination of gas-phase basicity of olefinic $\mathrm{C}_{5}$ aldehydes or acids and $\mathrm{C}_{6}$ ketones is made from the measurement of proton transfer equilibrium constants in ion cyclotron resonance experiments. The values, lying between 800 and $850 \mathrm{~kJ} \mathrm{~mol}^{-1}$, are compared with those obtained for lower homologues. The $\alpha, \beta$-unsaturated effect of substitution on the basicity of the carbonyl group is briefly discussed. It is generally observed that the gas-phase basicity of an acid is lower than that of the corresponding aldehyde.
\end{abstract}

The knowledge of gas-phase basicity (GB) and proton affinity (PA) leads to the determination of heats of formation of protonated species and allows the understanding of structural effects upon reactivity in the absence of solvent. From these points of view, polyfunctional molecules such as conjugated aldehydes, ketones, or acids constitute an interesting subject of investigation in view of their extensive use in organic synthesis. If there is now little doubt that for such molecules the thermodynamically most favorable protonation site is the oxygen of the carbonyl group, the quantitative estimate of the effect of alkyl or hydroxyl substitution upon protonation thermochemistry is poorly documented. ${ }^{1-4}$ The present study deals with the gas-phase protonation of aldehydes, ketones, and acids $1-9$ bearing $\alpha, \beta$-unsaturated $\mathrm{C}_{4} \mathrm{H}_{7}$ alkyl chains.

The determination of the GB of $1-9$ is made from the measurement of proton transfer equilibrium constants in ion cyclotron resonance (ICR) experiments. The PA values and the $\Delta H_{\mathrm{f}}{ }^{\circ}$ of the corresponding $\mathrm{C}_{5} \mathrm{H}_{9} \mathrm{O}^{+}, \mathrm{C}_{6} \mathrm{H}_{4} \mathrm{O}^{+}$, and $\mathrm{C}_{5} \mathrm{H}_{9} \mathrm{O}_{2}{ }^{+}$ions which are deduced are compared with those

\footnotetext{
${ }^{4}$ DCMR-Ecole Polytechnique.

*EPFL-Institut de Chimie Physique.
}

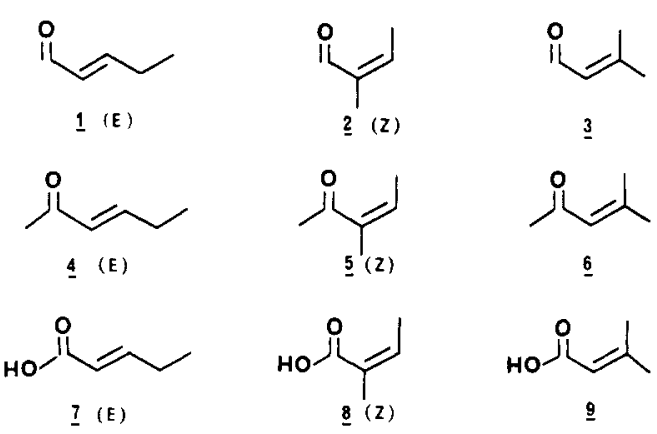

of lower homologues in order to draw conclusions as to the effects of substitution on the stability of the protonated species.

(1) Vajda, J. H.; Harrison, A. G. Int. J. Mass Spectrom. Ion Phys. 1979, 30, 293-306.

(2) Bouchoux, G.; Hoppilliard, Y.; Jaudon, P.; Houriet, R. Org. Mass. Spectrom, 1984, 19, 394-397.

(3) Kamar, A.; Young, A. B.; March, R. E. Can. J. Chem. 1986, 64, 2368-2370.

(4) Loncharich, R. J.; Schwartz, T. R.; Houk, N. K. J. Am. Chem. Soc. $1987,109,14-23$ and references cited therein.

(C) 1988 American Chemical Society 